\title{
Communications
}

\section{Société Suisse de Neurologie}

\section{Concours pour l'obtention du prix de la} Fondation Mogens et Wilhelm Ellermann

En septembre 2015, la Société Suisse de Neurologie attribuera pour la treizième fois le prix de la Fondation Mogens et Wilhelm Ellermann, d'un montant de 20000 francs, qui est destiné à récompenser

- un travail scientifique dans le domaine neurologique qui a été publié lors des deux dernières années ou qui a été accepté pour publication par une revue reconnue sur le plan international,

- une monographie qui n'a pas les caractéristiques d'un traité ni celles d'une revue de la littérature, ou encore

- l'ensemble d'une œuvre scientifique dans le domaine des sciences neurologiques.

Ce travail doit avoir été rédigé par un ou plusieurs chercheurs suisses ou par des chercheurs étrangers en activité dans une clinique ou un institut helvétique. La préférence sera donnée à des auteurs jeunes qui ne sont pas agrégés ou ne le sont que depuis peu.
Les lettres de candidature accompagnées d'un C. V. et d'une liste des publications (seulement travaux qui sont peer-reviewed) en 5 exemplaires, y compris les articles, doivent être adressées jusqu'au 29 février 2016 au Prof. Dr med. C. L. Bassetti, Chef de service, Clinique et Policlinique neurologique, Hôpital Universitaire de Berne, Inselspital, 3010 Berne.

Schweizerische Herzstiftung/ Fondation Suisse de Cardiologie

\section{Research Prize of the Swiss Heart} Foundation

The Swiss Heart Foundation awards an annual prize of $20000 \mathrm{CHF}$ for one or several outstanding publications / accepted manuscripts of scientific research in the field of prevention, diagnosis and/or treatment of cardiovascular diseases.

Swiss researchers or research teams working in Switzerland or abroad as well as foreign researchers working in Switzerland are entitled to participate. The age limit is 45 years at the time of application. Previous prize winners are not eligible for the prize. In addition, scientific publications, which have already been awarded or elected for another prize, are not eligible. The prize winner will be chosen by the Research Committee of the Swiss Heart Foundation. For further informations and detailed rules see www.swissheart.ch/ forschungspreis.

Applications should be submitted by 31st December (date of postmark) by post (one copy) as well as by e-mail with:

- one signed accompanying letter

- the publication(s)/ accepted manuscript(s) to be considered

- list of references

- brief curriculum vitae (max. 1 page)

to: Swiss Heart Foundation,

Research Committee, Schwarztorstrasse 18,

P.O. Box 368,3000 Bern 14 ,

Phone: 03138880 80, Fax: 0313888088. research[at]swissheart.ch

www.swissheart.ch/forschungspreis

\section{Sujets actuels de forum}

Joignez la discussion en ligne sur www.bullmed.ch

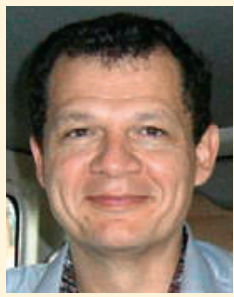

Dr med. Emmanuel Escard, Unité interdisciplinaire de médecine et prévention de la violence, Hôpitaux universitaires de Genève

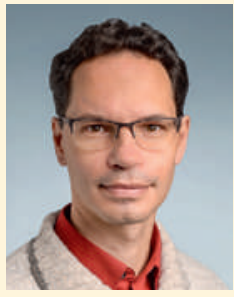

\section{Réalité et rationalité en psychiatrie}

Le mirage de la rationalité des comportements violents:

le réel n'est pas mesurable!

Dr med. Felix Wittlinger,

spécialiste en pédiatrie, FMH, médecin scolaire, Zurich

\section{Accès aux résultats d'études}

Tous les résultats d'études doivent être accessibles au public! 